\title{
部分空間法によるミクセル分解と超多波長画像への応用
}

\section{Unmixing with Subspace Method and Application to Hyper Spectral Image}

\author{
山形与志樹* \\ Yoshiki YAMAGATA
}

\begin{abstract}
A new approach of unmixing with the subspace method is proposed and an experiment using hyperspectral image was conducted. In stead of using conventional statistical unmixing procedures which incorporate all channel data to perform unmixing, the proposed approach assigns subspace for each unmixing class. In this method, unmixing is calculated by the projection of observed pixel vector on the class subspaces. This method is more stable than conventional methods against noises and works effectively as a feature extraction and data reduction procedure at the same time. Owing to these advantages, this approach is suitable for the unmixing of hyper spectral image which has high correlation between channels. The performance of this method is tested by an experimented using a hyper spectral airborne casi image acquired over a wetland area. Unmixing of 7 wetland vegetation classes were calculated using least square, quadratic programming, orthogonal subspace projection and subspace method. Finally, the results of unmixing experiment were compared and evaluated for the use of wetland vegetation monitoring.
\end{abstract}

\section{1.はじめに}

湿原域では，さまざまな湿原植生が相互に重なり合 い，連続的に変化して分布している。このような領域 を分光観測した画素の多くは, 複数の土地被覆クラス のスペクトル特性が混合したミクセル (Mixed pixel) になっている。しかしながら, リモートセンシング画 像解析において一般的に用いられてきた最尤法による 教師付き分類手法 (Richards 1993) は, 各クラスのスぺ クトル特性が正規分布に従い, かつ各画素のスペクト ルがどれかひとつの土地被覆クラスに対応しているこ とを前提にしているため, ミクセルを多く含んだ画像 解析には適していない。ミクセル画素の解析には, ミ クセルのスペクトル情報から各構成要素についての情 報を逆に推定するミクセル分解手法を用いる必要があ る（稲村1987）。

ミクセル分解に際して, 最も一般的に用いられてい

* 国立環境研究所社会環境システム部 305 つくば市小 野川 $16-2$

「写真測量とリモートセンシング」VOL. 36, NO. 3, 1996
る, 最小 2 乗法等による統計的ミクセル分解のアルゴリ ズムでは，構成要素の面積比率を係数として，ミクセ ルのスペクトルを構成要素スペクトルの線形結合で表 す線形ミクセルモデルが用いられている。このモデル を解くことによって，あらかじめ知られている構成要 素のスペクトルから, 構成要素の面積比率を推定する ことができる（Settle and Drake 1993,伊藤と藤村 1987)。しかしながらこれらの手法では, 画像のチャン ネル数が大きくなるに従って，ミクセル分解の計算量 が急増し, チャンネル間の相関により解が不安定にな る等の問題が生じるてしまう。そのため, ミクセルの 中にどの構成要素のスペクトルが含まれているかの検 定や，スペクトル次元の圧縮がミクセル分解の前処理 として必要であった（Malinowski 1991）。

近年のリモートセンシング技術の発展によって，さ らに細かな波長幅で分光画像計測する超多波長のセン サーが開発され，各種の環境計測に活用されつつある (Kramer 1992), 特に, 植生のパラメータを推定する ために，超多波長のリモートセンシング画像が有効で あることが認識されている(Gong 1994)。このような 発展にともない，何百チャンネルにもおよぶ超多波長 
のしかも大規模な画像を用いて，複数の植生が混在す るミクセルを安定的かつ高速にミクセル分解する手法 の確立が現在急務となっている。そこで，既存の統計 的手法に代わる信号処理やニューラルネットワーク等 の新手法を導入して，超多波長画像の波長選択，特徵 軸抽出，次元圧縮に関かわる研究が現在活発になされ つつあ (Harsanyi and Chang 1994,Benediktsson et.al 1995,喜安と藤村1995)。

本論文で新たに提案する部分空間法（オヤ1984）に よるミクセル分解手法は，従来の統計的な特徵選択と は全く異なった原理によって，大規模な超多波長の画 像を安定かつ高速に処理する手法である。部分空間法 によるミクセル分解では，これまでの線形ミクセルモ デルに基づいたアプローチに代わって，各クラスに部 分空間が対応していると考えて，部分空間への射影に よってミクセル分解するアプローチが用いられる。全 クラスに共通した，一定チャンネル数のスペクトル空 間の中でミクセルモデルを当てはめるのではなく，各 クラス毎に異なるスペクトル部分空間を割り当てて,

ミクセルの各クラス部分空間への射影の大きさによっ て分解を実現するのが部分空間法の特徵である。また， 従来の統計的手法では, 特徵抽出とミクセル分解が別 のプロセスとして分離していたのに対して，部分空間 法では特徵抽出とミクセル分解が部分空間への射影の 計算として一体化しているのも大きな特徵である。

本論文ではまず，新たに開発された部分空間法によ るミクセル分解の原理について説明し，次に実際に取 得された超多波長のスペクトル画像を用いたミクセル 分解の実験により，新手法を従来の各種統計的ミクセ ル分解の手法と比較検討した結果について報告する。

\section{2. 部分空間法によるミクセル分解の理論}

\section{1 統計的ミクセル分解}

従来の統計的ミクセル分解においては，ミクセルの スペクトルは，ミクセル中に存在する各地表面構成要 素のスペクトルを，それぞれの面積比率で重み付き平 均で表すことができる（線形ミクセルモデル）と仮定

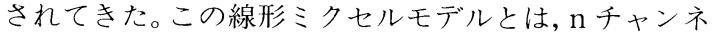
ルのリモートセンシング画像が取得され, 画像中 $\mathrm{K}$ 個 の土地被覆クラスが存在し, ミクセル画素中のクラス $\omega^{(\mathrm{i})}$ の面積比率を fi とするとき，各画素の観測べクト ル r が次式で表せるとするモデルである。
$r=M f+n=\sum_{i=1}^{K} f_{i} m_{i}+\mathrm{n}$

ここで $\mathrm{M}$ はクラス $\mathrm{i}$ の代表ベクトル $\mathrm{mi}$ を列にもつ 行列で，fは画素中に各クラスの面積比 fi を要素にも つベクトル，nはノイズを表すべクトルである。

統計的ミクセル分解の手法は, (1) 式の観測スペクト ル r とクラススペクトル行列 $\mathrm{M}$ が与えられた時に, 各 クラスの面積比べクトル $\mathrm{f}$ を計算するアルゴリズムで ある。統計的ミクセル分解の手法としては, 最小 2 乗法, 因子分析, 特異值分解等を用いたもの知られている(稲 村1987,伊藤と藤村1987, Malinowski1991, Settle and Drake 1993)。

一方，本報告で提案するミクセル分解の手法は，部 分空間法 (Watanabe 1969, Kohonen 1977, オヤ1984) を用いて今回新たに開発された手法であり，統計的な 手法と異なり，線形ミクセルモデルを前提とせずに， 各クラスにスペクトル部分空間を割り当てて，部分空 間への射影の大きさによってミクセル分解を実現する 手法である。

\section{2 部分空間法の考え方}

部分空間法の基本は，それぞれのクラスのスペクト ルペクトルが，スペクトルの全次元の空間の中にまん べんなく存在するのではなく，そのクラスに特徵的な 部分毕間の中に入っているという考えにある。そこで 部分空間法ではまず，クラス毎のトレーニングサンプ ルから，あらかじめ各クラスの特徵的な部分空間が決 定される。(Watanabe 1969，Kohonen 1977)。

従来の分類やミクセル分解手法おいては，まずスぺ クトル空間を定めて（場合によっては特徵軸に変換し た上で)，その中で判別の領域を設定したり，代表べク トルを求めて混合比率の推定が行われていた。部分空 間法においては，クラス毎に決定される部分空間に よって各クラスのスペクトル特性を特徵づけている点 が，これまでの手法とは根本的に異なっている。

部分空間法を計算するアルゴリズムには，部分空間 を決定する際の計算方法の違いに応じて，代数的部分 空間法，統計的部分空間法，学習部分空間法などがあ る(オヤ1984)。以下本論文では，ミクセル分解のよj なトレーニングデータが比較的少ない場合に, 高速に 部分空間を計算することができる統計的部分空間法の 一つである CLAFIC (CLAss-Featuring Information Compression)法によるアプローチを用いる。 


\section{3 改良 CLAFIC 法による部分空間の決定}

部分空間法では，クラス部分空間がそのクラスに属 するベクトルをできるだけ多く含むように，すなわち クラスベクトルの射影全体が大きくなるように部分空 間が決定される。CLAFIC 法は，各クラスベクトルの 対応する部分空間への射影の期待值を最大化する部分 空間の決定手法である。しかしながら，すべてのクラ 又部分空間毎に独立して射影が最大になるように部分 空間を決定しようとすると，類似したクラス間の分離 が劣化してしまう久点がある。そこで，当該クラスへ の射影を大きくし，同時に他クラスへの射影を小さく する改良型 CLAFIC 法が開発された（オヤ 1984）。本 研究ではこの改良型 CLAFIC を用いてミクセル分解 手法を提案する。以下に, 改良型 CLAFIC 法よる部分 空間の決定の手続きについて述べる。

改良型 CLAFIC 法では, $\mathrm{K}$ 個の土地被覆構成要素ク ラス $\omega^{(\mathrm{i})}$ に対応する部分空間 $\mathrm{L}_{(\mathrm{i})}$ を，クラス $\omega^{(\mathrm{i})}$ に属す るベクトル $\mathrm{x}$ の部分空間 $\mathrm{L}_{(\mathrm{i})}$ への射影が大きくなり, それ以外のクラス $\omega^{(\mathrm{j})}(\mathrm{j} \neq \mathrm{i})$ に属するべクトルの部分 空間 $\mathrm{L}_{(\mathrm{i})}$ への射影が小さくなるように決定する。この 条件を満たすように部分空間 $\mathrm{L}_{(\mathrm{i})}$ を決定する問題は, 部分空間への射影の大きさの期待值の差を計算する次 式を最小とする最適化問題となる。

$\sum_{\substack{j \neq i \\ j=1}}^{K} E\left(x^{t} P^{(i)} x \mid x \in \omega^{(j)}\right)-E\left(x^{t} P^{(i)} x \mid x \in \omega^{(i)}\right)$

ただしここで， $\mathrm{P}^{(\mathrm{i})}$ は $\mathrm{L}_{(\mathrm{i})}$ への射影行列である。

(2) 式第一項は，クラス $\omega^{(i)}$ 属さないベクトルの射 影であり，第二項はクラス $\omega^{(\mathrm{i})}$ に属するベクトルの射 影である。この差を最小とすることで，第一項を小さ く, 第二項を大きくすること，すなわちクラス心 $\omega^{(\mathrm{i})}$ 属 するべクトル $\mathrm{x}$ の部分空間 $\mathrm{L}_{(\mathrm{i})}$ への射影が大きくな $\eta$ ，それ以外のクラス $\omega^{(\mathrm{j})} \quad(\mathrm{j} \neq \mathrm{i})$ に属するベクトルの 部分空間 $\mathrm{L}_{(\mathrm{i})}$ への射影が小さくなるように部分空間 $\mathrm{L}_{(\mathrm{i})}$ を決定することが可能になる。

射影行列 $\mathrm{P}^{(\mathrm{i})}$ は部分空間 $\mathrm{L}_{(\mathrm{i})}$ の $\mathrm{p}_{(\mathrm{i})}$ 個の正規直交基定 $\left\{u_{1}{ }^{(i)}, \ldots, u_{(i)}{ }^{(i)}\right\}$ を用いて 次式で表わされる行列である。

$P^{(i)}=\sum_{k=1}^{p_{(i)}} u_{k}{ }^{(i)} u_{k}{ }^{(i) t}$

（3）式を(2)式に代入して，(2)式を基底べクトル $\mathrm{u}_{k}^{(i)}$ $\left(\mathrm{k}=1, \ldots, \mathrm{p}_{(\mathrm{i})}\right)$ を用いて表わし直すと次式が得られ る。 $\sum_{\substack{j \neq i \\ j=1}}^{K} \sum_{k=1}^{p_{(i)}} E\left(\left(x^{t} u_{k}{ }^{(i)}\right)^{2} \mid x \in \omega^{(j)}\right)-\sum_{k=1}^{p_{(i)}} E\left(\left(x^{t} u_{k}{ }^{(i)}\right)^{2} \mid x \in \omega^{(i)}\right)$

ここで各クラス毎の期待值を先にに計算すると(4) 式 は次のようになる。

$\sum_{\substack{j \neq i \\ j=1}}^{K} \sum_{k=1}^{p_{(i)}} u_{k}{ }^{(i)} Q^{(j)} u_{k}{ }^{(i)}-\sum_{k=1}^{p_{(i)}} u_{k}{ }^{(i)} Q^{(i)} u_{k}{ }^{(i)}$

ただしここで, $\mathrm{Q}^{(\mathrm{i})}$ は次式で定義されるクラス $\omega^{(\mathrm{i})} の$ 相 関行列である。

$Q^{(i)}=E\left(x x^{t} \mid x \in \omega^{(i)}\right)$

(5) 式と, 正規直交基底 $\left\{\mathrm{u}_{1}{ }^{(\mathrm{i})}, \ldots, \mathrm{u}_{P(i)}{ }^{(i)}\right\}$ の正規条件 $u_{k}{ }^{(i) t} u_{k}{ }^{(i)}=1, k=1, \cdots, \mathrm{p}_{(i)}$

とを合わせると, (2) 式の最適化問題は, ラグランジュ の末定乗数法によって，次式を最小化する問題に変形 される。

$\sum_{k=1}^{p_{(i)}} u_{k}{ }^{(i) t}\left(\sum_{\substack{j \neq i \\ j=1}}^{K} Q^{(j)}-\mathrm{Q}^{(i)}\right) u_{k}{ }^{(i)}-\sum_{k=1}^{p_{(i)}}\left(\lambda_{k}{ }^{(i)} u_{k}{ }^{(i) t} u_{k}{ }^{(i)}-1\right)$

この式の各基底ベクトル $u_{k}{ }^{(i)} \quad\left(\mathrm{k}=1, \ldots, \mathrm{p}_{(\mathrm{i})}\right)$ に対す る変分をとると, 次の方程式系が求まる。

$\left(\sum_{\substack{j \neq i \\ j=1}}^{K} Q^{(j)}-Q^{(i)}\right) u_{k}{ }^{(i)}=\lambda_{k}{ }^{(i)} u_{k}{ }^{(i)}, \quad k=1, \cdots, \mathrm{p}_{(i)}$

これより, 各類部分空間 $\mathrm{L}^{(\mathrm{i})}$ の基底べクトル $u_{k}{ }^{(i)}(\mathrm{k}=$ $\left.1, \ldots, \mathrm{p}_{(\mathrm{i})}\right)$ は, 次式で表される行列の固有べクトルで なければならないことがわかる。

$Q=\sum_{\substack{j \neq i \\ j=1}}^{K} Q^{(j)}-Q^{(i)}$

さらに，Qの第 $\mathrm{i}$ 固有值を $\lambda_{\mathrm{k}}{ }^{(\mathrm{i})}$ とすれば，(8) 式は

$\sum_{k=1}^{p_{(i)}} u_{k}{ }^{(i) t} Q u_{k}{ }^{(i)}=\sum_{k=1}^{p_{(i)}} \lambda_{k}{ }^{(i)} u_{k}{ }^{(i) t} u_{k}{ }^{(i)}=\sum_{k=1}^{p_{(i)}} \lambda_{k}{ }^{(i)}$

となるので，(8) 式を最小にするためには，正規直交 基底として $\mathrm{p}_{(\mathrm{i})}$ 個の最小固有值に対応する固有べクト ルを選べば良いことがわかる。1

部分空間 $\mathrm{L}^{(\mathrm{i})}$ は基底べクトル $u_{k}{ }^{(i)}\left(\mathrm{k}=1, \ldots, \mathrm{p}_{(\mathrm{i})}\right)$ に よって一意に決定されるので，すなわち以上の手続き によって，(2)式を最小化するように部分空間を決定す ることができた。

\section{4 部分空間法によるミクセル分解}

各クラスの基底ベクトル $u_{k}{ }^{(i)}\left(\mathrm{k}=1, \ldots, \mathrm{p}_{(\mathrm{i})}\right)$ が，相

1 ただし，ここで部分空間の次元 $\mathrm{p}_{(\mathrm{i})}$ は, 各クラスへの射影 の平均をどの程度の大きさにするかを決定するパラメー夕 であり, 固有值の值に応じて事前に決定されているものと する。 
関行列の最小固有值に対応する固有べクトルとして決 定されれば，(3) 式により射影行列 $\mathrm{P}^{(\mathrm{i})}$ を計算すること ができる。このとき，未知スペクトル $\mathrm{x}$ に対する，各 クラス部分空間 $\mathrm{L}^{(\mathrm{i})}$ 一の射影の大きさは次式で計算す ることができる。

$x^{t} P^{(i)} x=\sum_{k=1}^{p(i)}\left(x^{i} u_{k}^{(i)}\right)^{2}$

このクラス部分空間 $\mathrm{L}^{(\mathrm{i})}$ の射影の大きさは，スぺ クトル xのクラス $\omega^{(\mathrm{i})}$ への帰属度を表している。そこ でこの帰属度の自然な拡張として，スペクトルxに含 まれているクラス $\omega^{(\mathrm{i})}$ のクセル成分の抽出がこの部 分空間への射影に対応していると考えて，各クラスへ のミクセル分解をクラス部分空間への射影の大きさに より定義した。2

\section{3. スペクトル画像を用いた部分空間法に よるミクセル分解の実験}

部分空間法を用いたミクセル分解の手法が，超多波 長のスペクトル画像に対して有効に動作寸るかどうか を確認するために, casi (compact airborne spectral imager)の288チャンネルのスペクトル画像を用いて ミクセル分解の実験を実施し，従来の統計的なミクセ ル分解の手法による結果と比較し精度を検討した。

\section{1 解析画像}

解析に用いた超多波長のスペクトル画像は，1993年に 8月に釧路湿原の赤沼周辺の高層湿原域を中心として 取得した casi (compact airborne spectral imager)の 画像である。casi は $1.8 \mathrm{~nm}$ 幅で470nm から $920 \mathrm{~nm}$ ま でスペクトル計測できるセンサーを持ち，全部で288 チャンネルのバンドの観測画像を取得することができ る。casi の各種諸元と画像取得条件を表1に示す。撮影 は高度 $3000 \mathrm{~m}$ 上空からセス十404によって実施され， 飛行高度とデータレコーダーの転送速度の制約から地 上分解能は進行方向に長く $3.7 \times 12.6 \mathrm{~m}$ となった。画像

2 だだし，この帰属度は, 統計的ミクセル分解ように各クラ スの面積比率を表しているわけではなく，部分空間で表現 された各クラスのファジー類へのメンバーシップ值を表し ている值である。

3 casi では2次元 CCD を用いてスワッス方向の空間成分と スペクトル成分を同時に観測しているためバンド間のレジ ストレーション誤差は無い。
表 1 casi スペクトルモードの諸元と画像取得条件

スペクトルモードの諸元

$\begin{array}{lc}\text { バンド幅 } & 1.8 \mathrm{~nm} \\ \text { バンド数 } & 288 \text { チャンネル } \\ \text { バンド帯域 } & 410.3-923.7 \mathrm{~nm} \\ \text { 画素数 } & \text { 39pixel,486line } \\ \text { ダイナミックレンジ } & 12 \mathrm{bit}\end{array}$

撮影条件

$\begin{array}{lc}\text { 高度 } & 3000 \mathrm{~m} \\ \text { 速度 } & 200 \mathrm{~km} / \mathrm{s} \\ \text { 地上分解能 } & \text { スキャン方向 } 3.7 \mathrm{~m} \\ & \text { 進行方向 } 12.6 \mathrm{~m} \\ \text { 観測日 } & 1993 \text { 年 } 8 \text { 月 } 31 \text { 日 } \\ \text { 観測時 } & \text { 午前 } 11: 25-11: 30 \\ \text { 天候 } & \text { 快晴 }\end{array}$

中の各画素はこの分解能の中にある地上対象物の平均 的なスペクトル特性を捉えている。 3

オリジナル casi 画像のチャンネル間の違いの概略を 見るために, 全288チャンネルの中から40チャンネルお きに選んだ7つのチャンネルについて, 原画像を表示し た（図1）。はじめの4チャンネルが可視，残りの3千ャ ンネルが近赤外バンドである。中心に赤沼が見え，高 層湿原域を堤防道路が横切っているのが見える。撮影 地域内にはさまざまな湿原植生が分布しており，特に ヨシ，スゲ，イソツツジがミズゴケの上に部分的に重 複しつつ連続的に分布している。

尚，解析に先だって casi 画像に対して，航空機のロー リングによる歪の補正とキャリブレーションデータに 基づく各バンドデータの放射輝度補正を実施した。 (Babey and Soffer 1992)

4 釧路湿原の低層湿原を代表する草本植生がスゲとヨシ で, 高層湿原のミズゴケとイソツツジ,さらに周辺部に広く 見られるハンノキが分類できることによって，湿原植生の 全体像を把握することができる。

5 ミクセル分解のクラス数はチャンネル数よりも小さくな くてはならない。しかし，チャンネル間に相関があるため， 有効にミクセル分解できるクラス数はチャンネル数よりも 少なくなる。本解析に用いた casi 画像の場合, 主成分分析 の結果, 有効チャンネル数は15程度であった。 


\section{2 ミクセル分解クラス}

ミクセル分解に用いた7つの土地被覆クラス 4 のスペク トル特性を四 2 に示す。道路, 水を除いて他はすべて湿 原植生クラスである。この咸からわかるように,これ らの植生クラス間のスペクトル特性の違いは大変微妙 で，バンド数が少ないランドサット画像等では判別が 困難である5。またこれらの植生クラスは相互に重な り合いつつ連続的に変化しているため, 既存の分類手 法による解析には適さず, ミクセル分解により分布を 抽出する必要がある。

\section{3 ミクセル分解アルゴリズム}

部分空間法によってミクセル分解を実現する具体的処 理手順について以下に記军。

1）ミクセル分解する7つのクラスについて, 現地調査 によって確認されたそのクラスに対応するピュアピク セル (エンドメンバー) をそれぞれ9ピクセルずつ選択

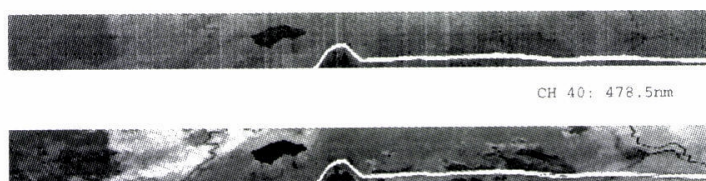

$\mathrm{CH} 8 \mathrm{C}: 549.5 \mathrm{~nm}$

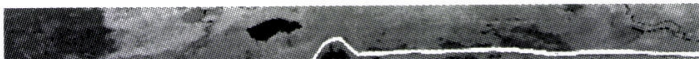

CH 120: $620.7 \mathrm{~mm}$

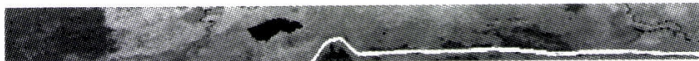

CH $260: 692,4 \mathrm{~nm}$

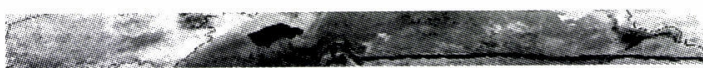

$\mathrm{CH} 200: 764.5 \mathrm{~nm}$

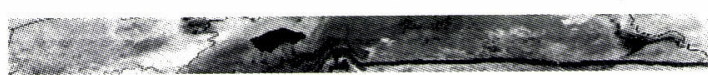

сн 240: $836.8 \mathrm{~mm}$

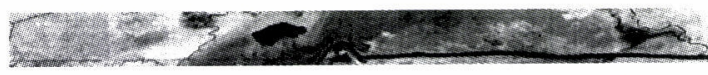

CH 280: $909.2 \mathrm{rm}$

図 1 選ばれた 7つのバンドの casi オリジナル画像

Spectral radiance of wetland vegetation

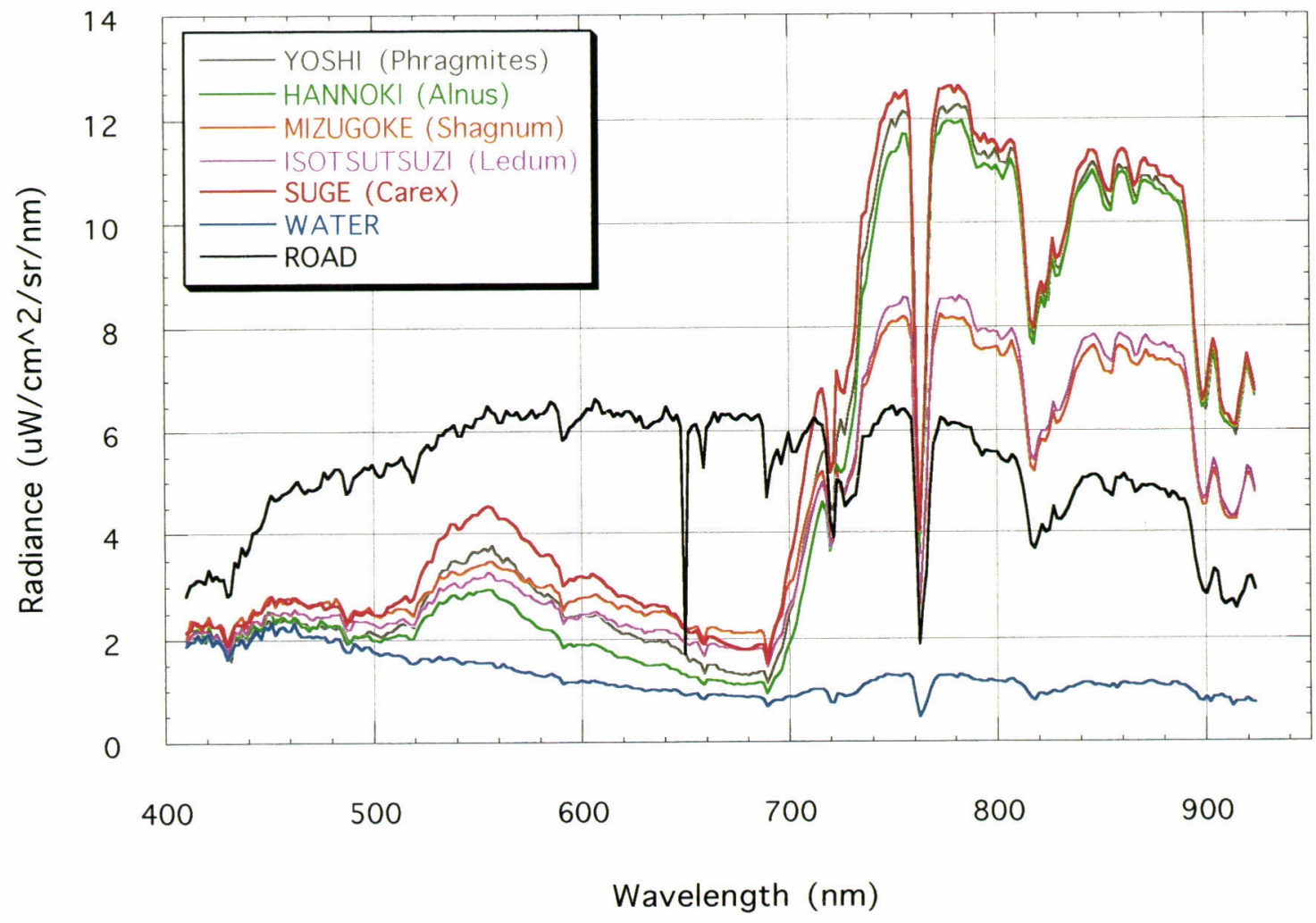

図 2 ミクセル分解に用いた 7 クラスのトレーニングスペクトル 
してトレーニングベクトルとする。

2) 各クラスのトレーニングベクトルを用いてクラス相 関行列 Qi を（6）式によって計算する。

3)それぞれのクラスの部分空間をクラス相関行列を用 いた（9）式の固有值問題を解いて決定する。（ただし 各クラスの部分空間の次元は共通して3次元とした。)

4）casi 画像の各ピクセルについて各クラスの部分空 間への射影を(12)式を用いて計算する。

5）射影（ミクセル分解の成分）を規格化（最大值が1 に，最小值が0になるように）して画像化する。

尚，本手続きによって casi 画像から計算された各クラ スの部分空間（基底べクトル）を表2に示す。基底べク トルは実際には288次元のベクトルであるが, 表示しき れないため, 図1で表示した7チャンネルに対応するべ クトルのみを示してある。

\section{4 ミクセル分解の各種手法}

部分空間法と比較するために用いた既存のミクセル

6 現地調査の結果については，2時期の航空機 MSS 画像 を用いた詳細な植生分類結果（小熊，山形1996）参照。
分解の手法は以下の3つである。

1）最小2乗法 ： 線形ミクセルモデルを仮定して, トレーニングベクトルを用いた最小2乗法によって各 クラスの面積率を求める方法。(稲村 1987 , 伊藤と藤村, 1987)

2) 2次計画法 : 線形ミクセルモデルに，各クラス の面積率の総和が1になるという条件を加えて，最小2 乗解を制約条件付きの2次計画法によって求める方法。 3) 直交部分空間射影法 : 他クラスの平均ベクトル が張る部分空間の直交補空間へのミクセルベクトルの 射影を求めて, さらにクラス平均ベクトルとの内積を 計算して各クラスのミクセル分解とする方法。（Harsany, 1994)

\section{5 ミクセル分解の結果}

部分空間法を用いて釧路湿原の casi 画像をミクセ ル分解した結果を図3に示す。また，既存の手法である

7 本論文のミクセル分解を計算するのに, NECのスーパー コンピュータ SX3を用いて，2次計画法では52秒，部分空間 法では5秒の計算時間を要した。

表 27 つのクラスに対応する部分空間の基底ベクトル（固有値ベクトル）

\begin{tabular}{|c|c|c|c|c|c|c|c|c|c|}
\hline CLASS & $\mathrm{PC}$ & EIGEN VALUE & & & GEN VI & TOR & & & \\
\hline & & & $478.5 \mathrm{~nm}$ & $549.5 \mathrm{~nm}$ & $620.7 \mathrm{~nm}$ & $692.4 \mathrm{~nm}$ & $764.5 \mathrm{~nm}$ & $836.8 \mathrm{~nm}$ & $909.2 \mathrm{~nm}$ \\
\hline YOSHI & 1 & -129.52 & -0.0173 & 0.0408 & -0.0053 & -0.0256 & -0.2552 & -0.0381 & -0.0236 \\
\hline & 2 & -2.25 & -0.0458 & 0.0249 & 0.0457 & 0.0010 & 0.0130 & -0.0167 & 0.0501 \\
\hline & 3 & -1.87 & -0.1464 & 0.0076 & -0.0140 & 0.0200 & 0.0235 & -0.0437 & -0.1009 \\
\hline HANNOKI & 1 & -337.47 & -0.0464 & 0.0763 & -0.0082 & -0.0107 & -0.1042 & -0.0525 & -0.0185 \\
\hline & 2 & -2.30 & -0.0232 & 0.0450 & -0.0110 & 0.0637 & -0.0131 & -0.0323 & -0.0378 \\
\hline & 3 & -2.17 & -0.0278 & -0.0173 & 0.0466 & -0.0402 & 0.0049 & 0.0233 & 0.0411 \\
\hline MIZUGOKE & 1 & -31.42 & -0.0505 & -0.0599 & 0.0166 & 0.0468 & -0.0654 & 0.0206 & 0.0239 \\
\hline & 2 & -2.72 & -0.0846 & 0.0278 & -0.0390 & 0.0552 & 0.0410 & 0.0267 & 0.0267 \\
\hline & 3 & -2.11 & 0.0137 & 0.0181 & 0.0297 & 0.0590 & 0.0366 & 0.0139 & 0.2041 \\
\hline ISOTSUTSUJI & 1 & -6.98 & 0.1075 & -0.0568 & -0.0076 & -0.0470 & -0.0205 & 0.0005 & 0.0539 \\
\hline & 2 & -1.74 & 0.0567 & 0.0022 & 0.0107 & 0.0081 & 0.0722 & 0.1964 & -0.1394 \\
\hline & 3 & -1.30 & 0.1149 & 0.0396 & -0.0430 & -0.0078 & -0.0041 & -0.0110 & -0.0146 \\
\hline SUGE & 1 & -146.98 & 0.0509 & -0.1038 & 0.0076 & 0.0328 & -0.1448 & 0.0094 & 0.0263 \\
\hline & 2 & -3.00 & -0.0570 & -0.0223 & 0.0409 & 0.0101 & -0.0545 & 0.0682 & 0.0515 \\
\hline & 3 & -2.08 & 0.0419 & 0.0229 & 0.0808 & 0.0391 & -0.0189 & 0.0644 & -0.1118 \\
\hline WATER & 1 & -604.14 & 0.0856 & 0.0215 & -0.0516 & -030621 & -0.0015 & -0.0108 & 0.0171 \\
\hline & 2 & -1.39 & -0.0654 & 0.0132 & 0.0252 & -0.0124 & -0.0353 & 0.0296 & 0.0476 \\
\hline & 3 & -0.89 & -0.0256 & -0.0013 & -0.0372 & -0.0115 & 0.0527 & -0.0566 & -0.1631 \\
\hline $\mathrm{ROAD}$ & 1 & -24656.21 & 0.0620 & 0.0711 & 0.0939 & 0.0836 & -0.0173 & -0.0293 & -0.0239 \\
\hline & 2 & -47.39 & -0.0146 & 0.0529 & 0.0654 & -0.1158 & -0.0247 & 0.0633 & -0.0073 \\
\hline & 3 & -5.04 & -0.0215 & -0.0564 & 0.0342 & 0.0676 & 0.0031 & -0.0031 & 0.0074 \\
\hline
\end{tabular}




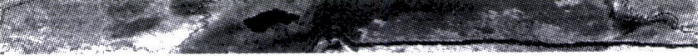

Yostis

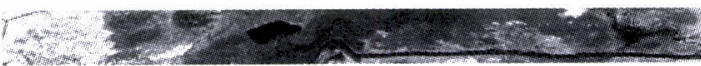

Nemroki

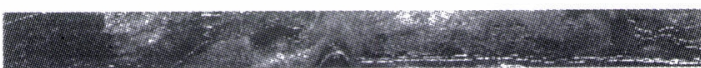

Nizugoke

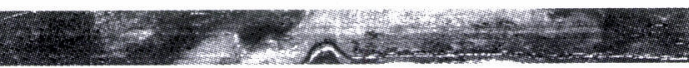

Isotivtuj:

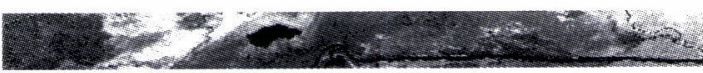

Suce

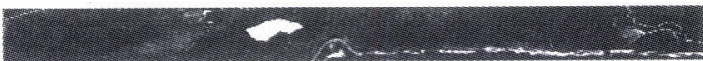

Wate

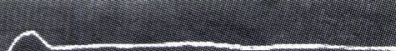

Roid

図 3 部分空間法によるミクセル分解の結果

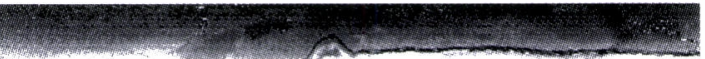

roshi

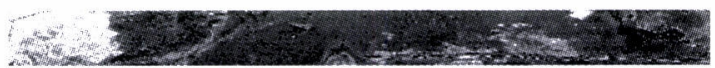

bamoki

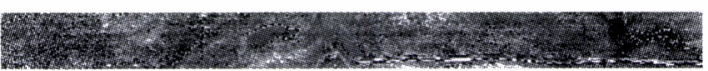

Mizugoke

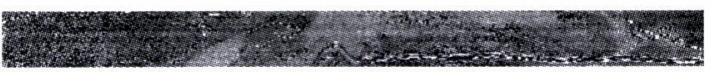

Isotutuji.

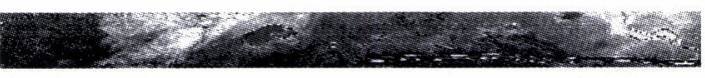

Suge

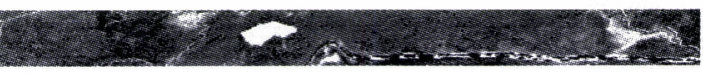

water

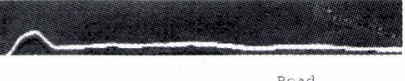

図4＼cjkstart最小２乗法によるミクセル分解の結果

最小2乗法, 制約条件付き二次計画法, 直交部分空間射 影法よりミクセル分解した結果をそれぞれ，四4, 図5, 四6に示す。ただし网中の濃度は，それぞれのクラスの ミクセル分解パターンが比較できるように, メンバー シップ值の最大值，及び最小值が255，0にそれぞれ対 忍するように表示されている。

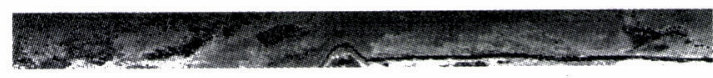

Yoshi

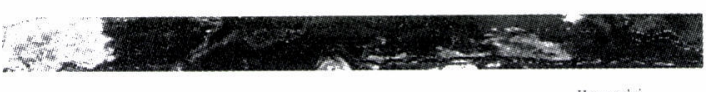

Hannoki.

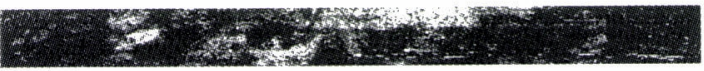

Mizugoke

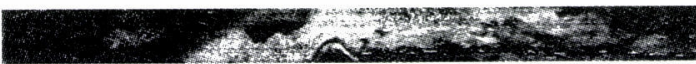

Isotutuji

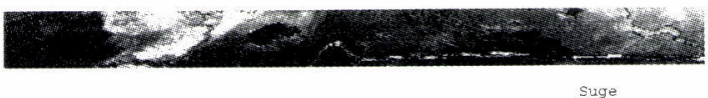

Suge

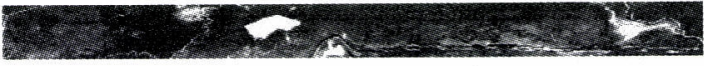

Water

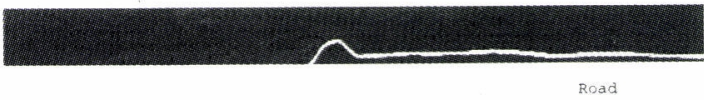

図 5 2 次計画法によるミクセル分解の結果

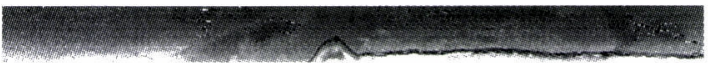

Yoshi

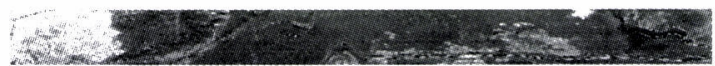

Hannoki

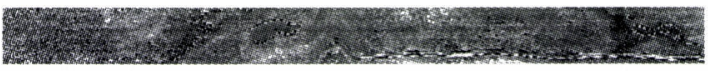

Mizugoke

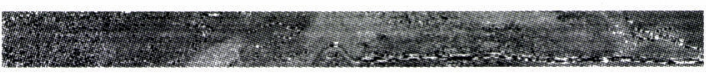
Isotutuji

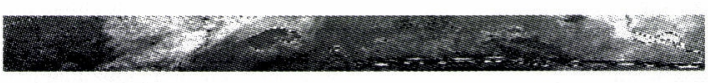

Suge

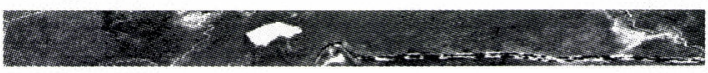

water

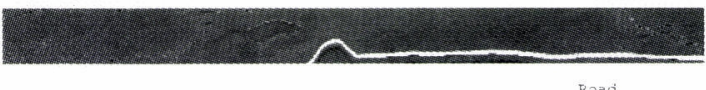

区 6 直交部分空間射影法によるミクセル分解の結果

部分空間法によるミクセル分解の精度を他の手法と比 較して，現地調查によって知られている実際の植生分 布のと対忍を調べたところ6, ミクセル分解の精度につ いて以下のような結果が得られた。

1）ヨシについては最小2乗法が最も現実に近いパター ンを示した。 
2）スゲについては部分空間法が2次計画法と並んで最 も現実に近いパターンを示した。

3) スペクトルパターンが極めて類似しているミズゴケ とイソツツジについては, 2次計画法のみが正確に判別 した。これは2次計画法では制約条件式によって,ミク セルをクラス間の微妙な違いをとられてどちらかにど のクラスかに属するようにミクセル分解が作用するた めと考えられる。

4)ハンノキについては，各手法ともほぼ正確な結果を 示したが，部分空間法では，ハンノキに近いスペクト ル特徵を持つヨシとの混同が見られた。

5) 水については, 部分空間法のみが水域を明確に分離 した。他手法では，水の分布が湿原域全体に広がる結 果が得られた。ただし，これは湿原植生の下やミズゴ ケに含まれる水分が抽出されたためとも考えられる。 6）道路については各手法とも良好な結果を示した。

\section{6 ミクセル分解手法の評価}

以上のミクセル分解の実験結果を基にしつつ, 各手 法に関する評価をまとめると以下の通りである。

1) 道路，水，スゲなどの他クラスとのスペクトル特性 の違いが明確なクラスのミクセル分解については, 部 分空間法によるミクセル分解は正確な結果を示す。

2) スペクトル特性が類似しているイソツツジとミズゴ ケなど, 分離が困難なクラスについては, 2次計画法が 最良の結果を示し, 部分空間法では分離できなかった。

3）直交部分空間射影（OSP）法による結果は，最小2 乗法による結果と完全に一致した。

4）総合的に判断して，2次計画法が最も現実に近いミ クセル分解の值を示したが, 2 次計画法問題を解くため に必要な制約条件付きの探索を行う計算時間に比べ て, 部分空間法は解法に必要とする時間が少ない利点 がある7。特にミクセル分解が内積演算により計算され るため並列处理に適している。

5)最小2乗法や2次計画法では, チャンネル間の多重線 形性が一般逆行列等の行列計算の際の不安定性を引き 起こす可能性があるが, 部分空間法では相関行列の固 有值が用いられ，固有值問題の解法には反復法などの 数值的に安定なアルゴリズムを用いることができる。

また，サンプル数が少ない場合についても，クラス部 分空間の次元を調整することで対応できるため，サン プル数にとらわれずに正確なエンドメンバーのみを用 いることができる利点がある。

\section{4. ま と め}

部分空間法を用いたミクセル分解の新手法を提案 し, 超多波長のスペクトル画像を用いた湿原植生ミク セル分解に応用した。部分空間法によるミクセル分解 の手法は，既存のミクセル分解の手法に比較して，学 習過程や分解過程に計算の高速性や超多波長画像に対 する数值的安定性において優れている。また，casi 画 像を用いた湿原植生のミクセル分解の実験を実施した ところ, 非常にスペクトル特性が類似している2つのク ラスを除いて，他手法に劣らぬミクセル分解の結果が 得られた。近い将来，リモートセンシング画像のチャ ンネル数が急速に増加し，また分解能が向上してます ます解析画像が大規模化する中で，計算の高速性・安 定性に特徵を持つ部分空間法は有力なミクセル分解手 法となることが期待できる。今後はさらに，極めてス ペクトル特徵が近いクラス間の分離処理を，部分空間 の決定のアルゴリズムに取り入れてゆく手法を開発す る予定である。

\section{5 。謝辞}

航空機データの取得と湿原植生調查に際して, 宇宙 開発事業団の小熊宏之氏に御協力頂きました。また, 本解析は環境庁地球環境研究総合推進費「人工衛星 デー夕等利用による湿地植生分布の調査に関する研 究」の一環として実施されました。関係各位に感謝の 意を表します。（受付日1996.3.6，受理日1996.5.14）

\section{参考文献}

1)稲村実：カテゴリー分解に基づくリモートセンシン グ画像データの解析, 電子情報通信学会論文誌, Vol. J70-C, No.2, pp.241-250, 1987

2）エルッキ・オヤ：パターン認識と部分空間法，産 業図書, 1984

3) 小熊宏之, 山形与志樹 : 2 時期航空機 MSS デー夕を 用いた湿原植生分類に有効な観測波長带の研究, 写真 測量とリモートセンシング，Vol.35，No.1， 1996 4）山形与志樹他：航空機 MSS 実験による湿原植生判 別に有効な波長帯の選定と植生分類画像の作成, 日本 リモートセンシング学会誌, 第15卷, 第3号，22-35, 1995 
5) Babey, S.K. and Soffer, R.J.: Radiometric calibration of the compact airborne spectrographic imager(casi), Canadian J. Remote Sensing, Vol.18, No.4, pp.233-242, 1993

6) Watanabe, S.: Knowing and guessing - a quantitative study of inference and information, John Wiley, New York, 1969

7) Kohonnen, T. : Associative memory - a system theoretical approach, Springer Verlag, Berlin -Heidelberg-New York, 1977

8) Benediktsson, J.A., Sveinsson, J.R., and Arnason, K. : Classification and feature extraction of AVIRIS data, IEEE Trans. Geoscience and Remote Sensing, Vol. 33, No.5, pp.1194-1205, 1995

9) Harsanyi,C. and Chang,C. : Hyperspectral image classification and dimensionality reduction: an orthogonal subspace projection approach, IEEE Trans. Geoscience and Remote Sensing, Vol. 33, No. 4, pp.779-785, 1994

10) Malinowski,E.R. : Factor analysis in chemistry, John Wiley \& Sons, 1991

11) Gong, P., Miller, R., and Spanner, M. : Forest canopy closure from classfication and spectral unmixing of scene components - multisensor evaluation of an open canopy, IEEE Trans. Goescience and Remote Sensing, Vol.32, No.5, pp.1067-1080, 1994

12）伊藤直史, 藤村貞夫：画素のカテゴリ一分解によ る面積比推定, 計測自動制御学会論文集, Vol.23, No.8, pp.800-805, 1987

13) Settle, J.J., and Drake, N.A. : Linear mixing and the estimation of ground cover proportions, Int. J. Remote Sensing, Vol.14, No.6, pp.1159-1177, 1993

14）喜安千弥，藤村貞夫：クラスの重要度を考慮 した高次元データからの逐次的特徴抽出, 計測自動制 御学会論文集, Vol.31, No.9, pp.1245-1251, 1995

15) Kramer,H.J. : Earth observation remote sensing - survey of missions and sensors, Springer -Verlag, 1992

16) Richards, J.A. : Remote sensing digital image analysis, Springer-Verlag, 1993 